\title{
Tingkat Berpikir Siswa dalam Memecahkan Masalah Geometri Bangun Datar Ditinjau dari Kemampuan Matematika dan Gender
}

\author{
Finsensius Y. Naja ${ }^{1}$, Sofia Sa'o ${ }^{2}$, Agustina $\mathrm{Mei}^{3}$ \\ 1, 2, 3 Program Studi Pendidikan Matematika, Fakultas Keguruan dan Ilmu Pendidikan, Universitas Flores, \\ Jl. Samratulangi Ende, Flores, NTT, Indonesia \\ naja.finsensius@gmail.com
}

\begin{abstract}
Mathematics is an exact subject taught in schools and geometry is quite a matter of concern. The vanHiele thinking levels are: Visualization, Analysis, Abstraction, Deduction and Rigor thinking levels. The objectives of this study were (1) to determine the thinking level of male students with high, medium and low capabilities who were at the level of visualization, (2) to determine the level of thinking of female students with high, medium and low abilities who were at the Analysis level. This type of research is exploratory research using a qualitative approach. The subjects in this study were students of grade VII SMP, the research was carried out in January 2021. The instruments in this research were the researcher's main instrument and the supporting instrument for the Problem Solving Test. The results of this study, it was found that three male subjects who had high, medium and low math abilities and one female subject who had high mathematics were at the level of thinking analysis while two female subjects who had moderate and low math abilities were at the visualization thinking level. Subjects have a weakness in using imprecise properties to distinguish, identify, and select geometric shapes.
\end{abstract}

Keywords: Thinking, Geometry, Ability, Mathematics, Gender

\begin{abstract}
Abstrak
Matematika adalah pelajaran eksak yang diajarkan di sekolah dan geometri merupakan materi yang cukup memprihatinkan. Adapun tingkat berpikir vanHiele yaitu: tingkat berpikir Visualisasi, Analysis, Abstraksi, Deduksi dan Rigor. Tujuan penelitian ini adalah (1) untuk mengetahui tingkat berpikir siswa laki-laki yang berkemampaun tinggi, sedang dan rendah yang berada pada level visualisasi, (2) untuk mengetahui tingkat berpikir siswa perempuan yang berkemampuan tinggi, sedang dan rendah yang berada pada level Analysis. Jenis penelitian ini adalah penelitian eksploratif dengan menggunakan pendekatan kualitatif. Subjek dalam penelitian ini siswa kelas VII SMP, peneitian dilaksanakan pada bulan Januari 2021. Instrumen dalam peneitian ini yaitu instrumen utama peneliti sendiri dan instrumen pendukung Tes Pemecahan Masalah. Hasil penelitian ini, diperoleh tiga subjek laki-laki yang memiliki kemampuan matematika tinggi, sedang dan rendah dan satu subjek perempuan yang memiliki matematika tinggi berada pada tingkat berpikir analysis sedangkan dua subjek perempuan yang memiliki kemampuan matematika sedang dan rendah berada pada tingkat berpikir visualisasi. Subjek memiliki kelemahan dalam hal menggunakan sifat-sifat yang tidak tepat untuk membedakan, mengidentifikasi, dan memilih bangunbangun geometri.
\end{abstract}

Kata kunci: Berpikir, Geometri, Kemampuan, Matematika, Gender

Copyright (c) 2021 Finsensius Y. Naja, Sofia Sa'o, Agustina Mei

Corresponding author: Finsensius Y. Naja

Email Address: naja.finsensius@gmail.com (Jl. Samratulangi Ende, Flores, NTT, Indonesia)

Received 14 April 2021, Accepted 20 April 2021, Published 20 April 2021

\section{PENDAHULUAN}

Pendidikan mempunyai peranan yang amat penting untuk menjamin perkembangan dan kelangsungan hidup suatu bangsa. Pendidikan merupakan salah satu sektor pembangunan yang sangat memerlukan perhatian. Ada berbagai macam pelajaran yang diajarkan di sekolah, baik itu pelajaran eksak maupun non eksak. Matematika adalah salah satu pelajaran eksak yang diajarkan di sekolah. Pelajaran matematika yang diajarkan di sekolah ini lebih dikenal sebagai matematika sekolah. Menurut (Soedjadi 2020), matematika sekolah adalah unsur-unsur atau bagian-bagian matematika yang dipilih atas dasar: (1) Makna kependidikan yaitu untuk mengembangkan kemampuan dan kepribadian peserta 
didik. (2) Tuntutan perkembangan yang nyata dari lingkungan hidup yang senantiasa berkembang seiring dengan kemajuan ilmu dan teknologi.

Dengan adanya matematika sekolah diharapkan siswa tidak hanya terampil dalam mengerjakan soal-soal matematika, tetapi dapat menerapkan permasalahan matematika di dalam dunia nyata. Seperti yang diungkapkan (Soedjadi 1994), yaitu tujuan diajarkan matematika di setiap jenjang pendidikan pada dasarnya mengacu pada: (1) Tujuan yang bersifat Formal: yaitu tujuan yang menekankan kepada penataan nalar anak dan pembentukan sikap anak. (2) Tujuan yang bersifat Material: yaitu tujuan yang menekankan kepada keterampilan hitung, menyelesaikan soal dan penerapan matematika.

Jadi diharapkan siswa tidak hanya bergulat dengan matematika di sekolah saja, tetapi bisa menerapkannya ke dalam dunia nyata, sehingga dapat mengembangkan kemampuan berpikir logis, sistematis dan kritis dan menjadi manusia pembangun yang tekun, kreatif, cerdas dan bertanggung jawab serta mampu menyelesaikan masalah.

Geometri merupakan salah satu pokok bahasan dalam matematika yang posisinya cukup memprihatinkan, hal ini dapat kita lihat kenyataan di lapangan bahwa masih banyak siswa yang memiliki prestasi rendah dalam pokok bahasan geometri. Hal ini diungkapkan oleh (Soedjadi 1991) yaitu bahwa unit Geometri nampak merupakan unit dari pelajaran matematika yang tergolong sulit. Pendapat tersebut dibenarkan oleh hasil Penelitian (Sunardi 2020) menunjukan bahwa secara umum pemahaman siswa SMP tentang konsep-konsep geometri, unsur-unsur geometri dan logika penalarannya masih kurang (Suyatno 2005). Demikian juga hasil penelitian (Ponter 2001) bahwa siswa masih belum menguasai konsep dalam geometri, penelitian di SMA menunjukan bahwa masih ada siswa yang hasil tes geometrinya kurang memuaskan jika dibandingkan dengan materi matematika yang lain.

Salah satu materi geometri di kelas VIII SMP adalah segiempat. Materi segiempat ini cukup penting dipelajari karena materi segiempat merupakan salah satu materi prasyarat dalam mempelajari materi bangun ruang di kelas IX. Agar siswa bisa menguasai dan memahami bangun ruang, maka hendaknya siswa harus terlebih dahulu memahami materi bangun datar terlebih dahulu, salah satunya adalah segiempat.

Menurut (Suwarsono 1990), dalam mengembangkan kemampuan berpikir secara deduktifaksiomatis para pendidik matematika perlu memahami dan memperhatikan tingkat kemampuan berpikir siswa dalam geometri. Berkaitan dengan tingkat kemampuan berpikir geometri siswa, pasangan suamiistri (Van de Walle 2001) menghasilkan suatu penelitian yang membagi tingkat berpikir siswa dalam belajar geometri, kemudian hasil penelitian ini dikenal sebagai Teori van Hiele.

Van Hiele (Welle \& John, 2001) mengemukakan bahwa berpikir geometri melalui lima tingkatan. Lima tingkatan tersebut ialah Level 0 (visualization), dalam tingkat ini siswa berpikir tentang konsep-konsep dasar geometri, seperti bangun-bangun yang sederhana, terutama berdasarkan apa yang tampak secara utuh sebagai satu kesatuan tanpa memperhatikan sifat-sifat dari komponenkomponennya. Siswa pada tingkat ini sudah mengenal bangun-bangun geometri seperti persegipanjang, persegi kemudian jajargenjang dan sebagainya. Berdasarkan wujud tampilan dari bangun-bangun itu 
secara nyata. Siswa dalam tingkat ini belum mampu mencirikan bangun-bangun tersebut, misalkan: trapesium memiliki sepasang sisi yang sejajar. Siswa dalam tingkat ini juga belum dapat menerima sifatsifat atau konsep-konsep geometri secara pengertian tetapi hanya sekedar hafalan.

Level 1 (analysis), dalam tingkat ini siswa berpikir tentang konsep-konsep geometri berdasarkan analisis bagian-bagian komponen dan atribut secara informal. Dapat menentukan syarat-syarat perlu suatu konsep. Siswa dalam tingkat ini sudah mengetahui sifat-sifat dari suatu segi empat (persegipanjang, persegi, jajargenjang dan lain sebagainya), misalkan: sepasang sisi suatu trapesium sejajar, terdapat sepasang sudut sama besar pada suatu layang-layang. Level 2 (informal deduction), dalam tingkat ini siswa memahami sifat-sifat dari konsep-konsep menurut susunan yang logis. Membentuk definisi-definisi abstrak dan dapat membedakan antara syarat perlu dan cukup dari sekumpulan sifat dalam menentukan suatu konsep. Dalam tingkat ini siswa dapat menentukan strukturstruktur bangun-bangun datar segiempat, di samping itu siswa sudah dapat diajak berpikir secara deduktif-aksiomatif dan dapat membentuk suatu struktur geometri yang sifatnya abstrak walaupun sifatnya informal.

Level 3 (deduction), dalam tingkat ini siswa berpikir secara formal dalam konteks sistem matematika, melengkapinya dalam undefined term, aksioma-aksioma, sistem logika mendasar, definisidefinisi dan teorema-teorema. Siswa dalam tingkat ini sudah dapat diajak berpikir secara deduktif formal. Bukti-bukti dari suatu teorema sudah tidak lagi dibuktikan dengan menggunakan induktif tetapi sepenuhnya secara deduktif dengan menggunakan unsur-unsur geometri seperti pengertian pangkal, aksioma, definisi dan teorema, walaupun belum memahami secara sungguh-sungguh mengapa aksioma itu dimunculkan. Siswa dalam tingkat ini belum mampu apakah aksioma yang digunakan sudah tepat atau belum dalam struktur geometri yang bersangkutan. Level 4 (rigor), dalam tingkat ini siswa dapat membandingkan sistem-sistem berdasarkan pada aksioma-aksioma yang berbeda dan dapat menelaah bermacam-macam geometri tanpa menghadirkan teori-teori kongkrit. Siswa dalam tingkat ini sudah dapat berpikir jernih mengapa dalam suatu struktur geometri menggunakan aksioma-aksioma tertentu.

Menurut Keyes dan Anne (Musa 2016) tahap- tahap berpikir van Hiele akan dilalui siswa secara bertahap. Jadi, Tiap level, menjelaskan bagaimana proses berpikir siswa dalam belajar geometri, kemampuan pemahaman belajar siswa, kemampuan komunikasi matematika siswa, serta obyek yang masih kurang jelas menjadi obyek yang jelas. Tiap-tiap tingkat berpikir memiliki kriteria yang berbeda. Sehingga, tiap level menunjukkan kemampuan berpikir yang digunakan siswa dalam belajar geometri. Penelitian yang dilakukan oleh (Burger, William F \& Shaughnessy 1986) menghasilkan data yang cukup untuk menyusun suatu indikator (karakteristik) tingkat-tingkat perkembangan berpikir geometri teori van Hiele, namun penelitian tersebut hanya memberikan indikator untuk tingkat 0 sampai tingkat 3 .

Manusia diciptakan oleh Tuhan berbeda-beda, ada yang dilahirkan menjadi seorang laki-laki dan adapula diciptakan menjadi seorang perempuan. Diantara laki-laki dan perempuan terdapat kelebihan dan kekurangan masing-masing. Begitu juga dengan kemampuan berpikir antara laki-laki dan perempuan juga berbeda, seperti yang diungkapkan oleh (Maccoby, E.E. \& Jacklin 1985) bahwa laki- 
laki dan perempuan mempunyai beberapa perbedaan kemampuan, antara lain: (1) Perempuan mempunyai kemampuan verbal lebih tinggi dari-pada laki-laki. Selama periode awal sekolah sampai awal masa remaja, kedua jenis kelamin sama kemampuan verbalnya. Kira-kira umur 11 tahun, kedua jenis kelamin berbeda dengan keunggulan pada perempuan. (2) Laki-laki lebih unggul dalam kemampuan visual-spatial (penglihatan-ruang). Keunggulan laki-laki pada visual spatial ditemukan secara konsisten pada masa remaja dan dewasa (sekitar 12 ke atas), tidak pada masa kanak-kanak. Namun kedua jenis kelamin mempunyai kemampuan yang hampir sama dalam "analytic and nonanalytic spatial". (3) Laki-laki lebih unggul dalam kemampuan matematika. Kedua jenis kelamin sama dalam konsep kuantitatif mereka dan dalam penguasaan aritmetika pada masa sekolah dasar. Mulai kirakira umur 12-13 tahun keterampilan matematika laki-laki meningkat lebih cepat daripada perempuan.

Tetapi adapula yang tidak setuju atas pandangan yang menyatakan bahwa adanya perbedaan intelektual antara laki-laki dan perempuan adalah hasil ketidaksamaan proses pendidikan dan pengajaran yang diterima di sekolah, ketidaksetujuan ini diungkapkan oleh (Krutetskii 1976) yang menyatakan bahwa perbedaan tersebut terjadi karena adanya "internal inclination" yang berbeda, yakni perempuan kurang cakap dalam berpikir abstrak dan berpikir logis.

Begitu pula Annie E. Cameron (Krutetskii 1976) menyatakan bahwa perbedaan antara kemampuan laki-laki dan perempuan dalam konsep ruang, laki-laki lebih unggul. Juga dikatakan bahwa laki-laki lebih dapat menguasai bayangan bentuk-bentuk yang lebih kompleks. Selanjutnya (Krutetskii 1976) menggeneralisasi dari pendapat beberapa ahli sebagai berikut: (1) Laki-laki lebih unggul dalam penalaran logis, perempuan lebih unggul dalam ketepatan, ketelitian, kecermatan dan keseksamaan berpikir. (2) Laki-laki mempunyai kemampuan matematika dan mekanika lebih baik daripada perempuan. Perbedaan ini tidak nyata pada tingkat sekolah dasar, namun pada tingkat lebih tinggi mulai tampak.

Segiempat adalah gabungan dari empat ruas garis yang tepat dua-dua ujung ruas garis tersebut saling bertemu pada sebuah bidang datar dan tidak ada tiga titik temu yang segaris. Bangun segiempat dapat dikelompokkan atas persegi panjang, persegi, jajargenjang, belah ketupat, trapesium dan layanglayang. Bangun-bangun tersebut jika didefinisikan secara analitis atau sering disebut juga sebagai definisi analitik (Soedjadi 2020) yaitu dengan menyebutkan genus proximum dan differensia spesifica adalah sebagai berikut. Trapesium adalah segiempat yang memiliki tepat sepasang sisi yang sejajar. Trapesium sebarang adalah trapesium yang keempat sisinya tidak sama panjang. Trapesium samakaki adalah trapesium yang memiliki sepasang sudut yang berdekatan lancip dan sama besar. Trapesium siku-siku adalah trapesium yang salah satu sudutnya $90^{\circ}$. Jajargenjang adalah segiempat yang memiliki sepasang-sepasang sisi yang sejajar. Belah ketupat adalah jajargenjang yang sisinya sama panjang. Persegi panjang adalah jajargenjang yang salah satu sudutnya $90^{\circ}$. Persegi adalah belah ketupat yang sudutnya $90^{\circ}$. Persegi dapat juga didefinisikan sebagai persegi panjang yang sisinya sama panjang. Layang-layang adalah segiempat yang memiliki tepat sepasang sudut yang berhadapan sama besar dan sepasang-sepasang sisi yang berdekatan sama panjang. 
Tujuan dari penelitian ini adalah (1) untuk mengetahui tingkat berpikir siswa laki-laki yang berkemampaun tinggi, sedang dan rendah yang berada pada level visualisasi geometri vanHiele, (2) untuk mengetahui tingkat berpikir siswa perempuan yang berkemampuan tinggi, sedang dan rendah yang berada pada level Analysis geometri van Hiele. Jenis penelitian ini adalah penelitian eksploratif dengan menggunakan pendekatan kualitatif naturalistik.

\section{METODE}

\section{Jenis Penelitian}

Menurut Bogdan dan Taylor penelitian kualitatif adalah prosedur penelitian yang menghasilkan data deskriptif berupa kata-kata tertulis atau lisan dari orang dan perilaku yang dapat diamati. (Lexy. $\mathbf{J}$ Moleong 2013). Jenis penelitian dalam penelitian ini adalah penelitian eksploratif dengan menggunakan pendekatan kualitatif. Penelitian dilakukan oleh 6 siswa dengan rincian tiga siswa laki-laki dan tiga siswa perempuan dengan mengunjungi rumah dari subjek penelitian yang akan diteliti. Walaupun penelitian dilakukan di rumah subjek penelitian, namun tidak mengurangi keakurat data. Penelitian pertama dilakukan oleh tiga siswa laki-laki bertempat disalah satu kediaman subjek penelitian yaitu perumahan BTN, Jalan Anggrek Ende. Kemudian penelitian kedua dilakukan oleh tiga siswa perempuan bertempat disalah satu kediaman yaitu Jalan Melati Ende. Penelitian dengan judul Tingkat Berpikir Siswa Dalam Memecahkan Masalah Geometri. Penelitian dilaksanakan mulai tanggal 08 Januari sampai 05 Februari 2021.

Penggunaan pendekatan kualitatif naturalistik didasarkan atas pertimbangan bahwa penelusuran tingkat berpikir van Hiele perlu dilakukan dengan mengamati karakteristik proses berpikir subjek penelitian selama subjek penelitian melakukan kegiatan geometri. Pengamatan terhadap subjek penelitian disertai dengan wawancara terhadap subjek penelitian agar peneliti dapat mengetahui proses berpikir yang digunakan oleh subjek penelitian dalam melakukan kegiatan tersebut.

\section{Subjek Penelitian}

Subjek penelitian yang diambil dalam penelitian ini adalah 6 siswa, dengan rincian 3 siswa lakilaki dengan kemampuan tinggi, sedang, dan rendah serta 3 siswa perempuan dengan kemampuan tinggi, sedang, dan rendah. Pemilihan siswa-siswa SMP kelas VIIIB ini dikarenakan siswa-siswa tersebut telah menerima materi geometri bangun datar segiempat, sehingga diharapkan tingkat berpikir geometri siswa mudah ditelusuri.

\section{Instrumen Penelitian}

Dalam penelitian kualitatif, peneliti merupakan instrumen kunci, dan penelitian kualitatif ini lebih menekankan proses dari pada hasil. Walaupun peneliti merupakan instrumen kunci, namun selama kegiatan pengambilan data, peneliti menggunakan pedoman yang berisi daftar-daftar kegiatan geometri yang harus dikerjakan oleh subjek penelitian dan pedoman wawancara selama wawancara berlangsung. Pedoman wawancara terstruktur ini memuat pedoman wawancara untuk bangun segiempat. (Kho 1996) Pedoman wawancara untuk bangun segiempat terdiri dari enam kegiatan yang berkaitan dengan: (1) 
Menggambar bangun-bangun segiempat, (2) Menemu, menunjukkan dan mendefinisikan segiempat, (3) Menseleksi bangun-bangun segiempat, (4) Menebak bangun misteri, (5) Keekuivalenan dua definisi jajargenjang, (6) Penerapan bangun segiempat.

\section{Teknik Analisis Data}

Analisis data yang dilakukan selama penelitian ini sesuai dengan yang diutarakan oleh Miles dan Huberman (Kho 1996) yaitu untuk menganalisis data melalui tiga tahap: (1) tahap reduksi data, tahap ini dilakukan proses menseleksi dan menyederhanakan data, sehingga terjadi pengurangan data yang tidak perlu. Kegiatan ini dilakukan dengan mendengarkan rekaman wawancara secara berulangulang dan langsung diketik dan diberi kode. (2) tahap penyajian data, tahap ini kumpulan data diorganisasikan dan dikategorikan sehingga memungkinkan penarikan kesimpulan dan tindakan. Data yang dianalisis diklasifikasikan berdasarkan masing-masing subjek penelitian. (3) tahap penarikan kesimpulan, tahap ini dilakukan penarikan kesimpulan pada setiap kegiatan wawancara kepada siswa.

\section{HASIL DAN DISKUSI}

Analisis data berpikir siswa subjek pertama S1 adalah sebagai berikut, siswa S1 hanya dapat menggambar 6 segiempat. Adapun keenam gambar segiempat tersebut adalah sebagai berikut.

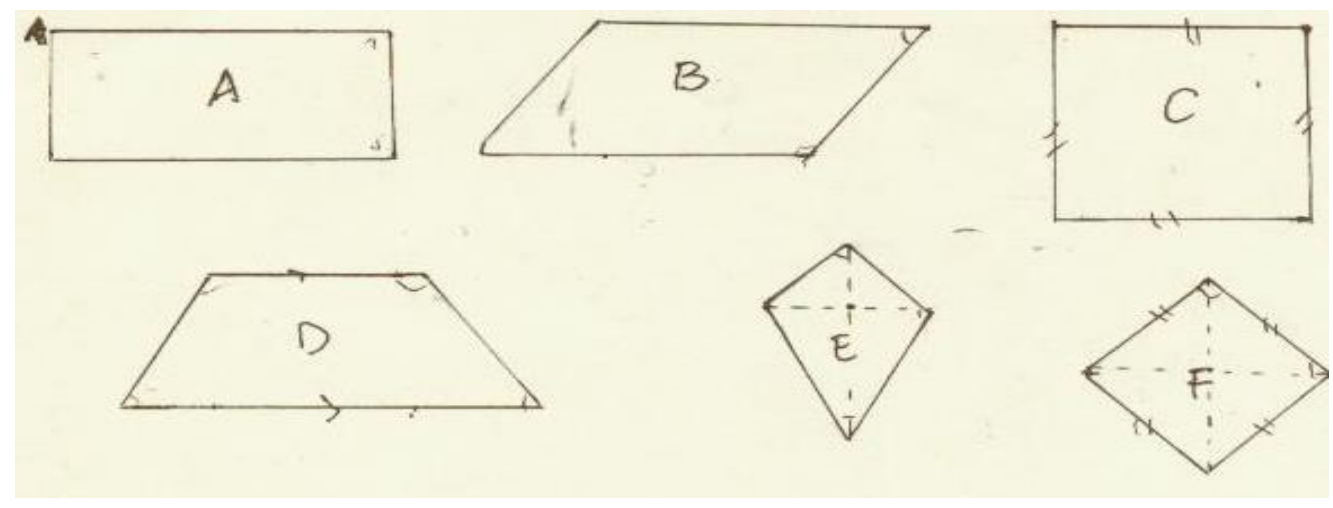

Gambar 1. Macam Segiempat menurut S1

Tingkat berpikir subjek pertama S1 lebih banyak pada tingkat berpikir analisis (1). Dari hasil analisis tiap kegiatan yang dilakukan S1, masih ada beberapa kelemahan yang dimiliki, antara lain S1 masih belum bisa membayangkan bahwa banyaknya bangun segiempat berbeda adalah tak hingga, S1 masih belum memahami class inclusion, serta masih belum begitu memahami keekuivalenan dua definisi jajargenjang serta pembuktian matematika. Tetapi analisis S1 dalam mengklasifikasi bangunbangun segiempat berdasarkan sifat-sifat yang dimiliki oleh setiap bangun sudah mulai tampak. Jadi dapat disimpulkan bahwa tingkat berpikir S1 berada pada tingkat berpikir analisis (1).

Analisis data pada siswa Subjek kedua S2 berikut ini didasarkan atas hasil wawancara. S2 hanya mampu menggambar 7 bangun datar. Adapun bangun datar dapat dilihat pada gambar 2. Dalam membandingkan satu segiempat dengan segiempat lain, S2 mengacu pada atribut sisi, bentuk dan besar sudut yang berbeda. Selain itu siswa juga dapat menyebutkan bahwa banyaknya bangun segiempat yang dapat digambar adalah banyak tak hingga.Tingkat berpikir siswa S2 lebih banyak pada tingkat berpikir 
analisis (1), meskipun pada kegiatan pertama siswa S2 telah menunjukkan ciri-ciri dari tingkat 2 yaitu siswa telah memahami bahwa banyaknya bangun segiempat berbeda yang dapat digambar adalah tak hingga banyak. Jadi dapat disimpulkan bahwa tingkat berpikir siswa S2 berada pada tingkat berpikir analisis (1).
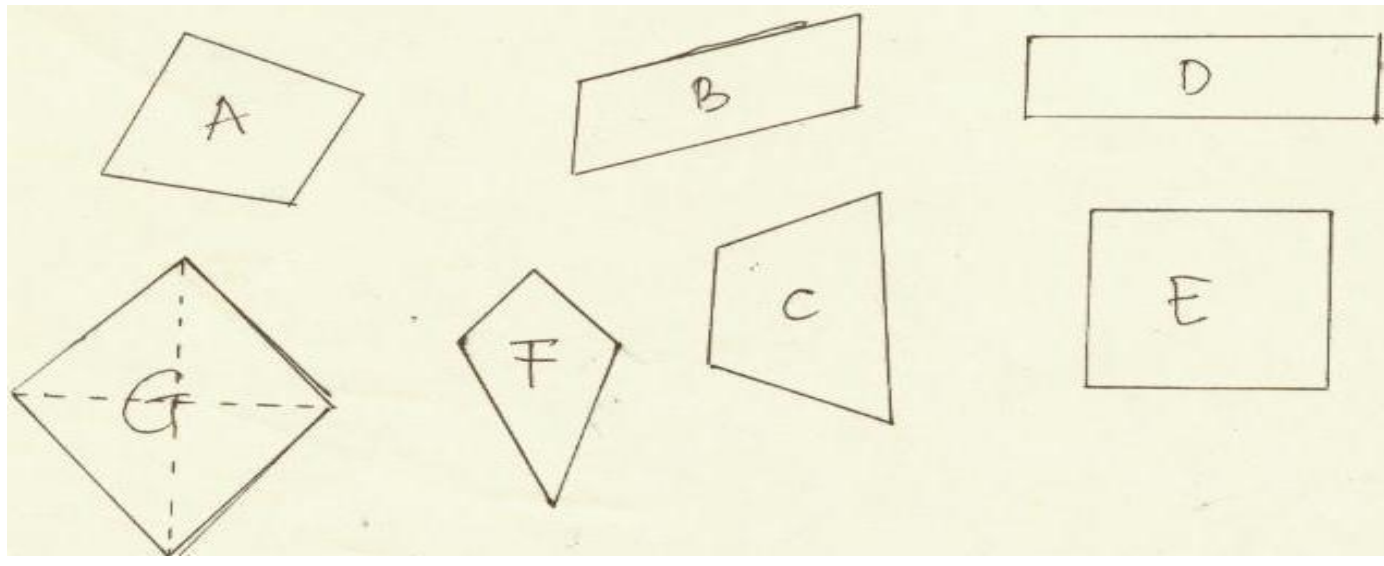

Gambar 2. Macam Segiempat menurut S2

Analisis data berpikir siswa S3 adalah sebagai berikut, siswa S3 hanya dapat menggambar 6 segiempat. Adapun gambar segiempat tersebut adalah sebagai berikut.
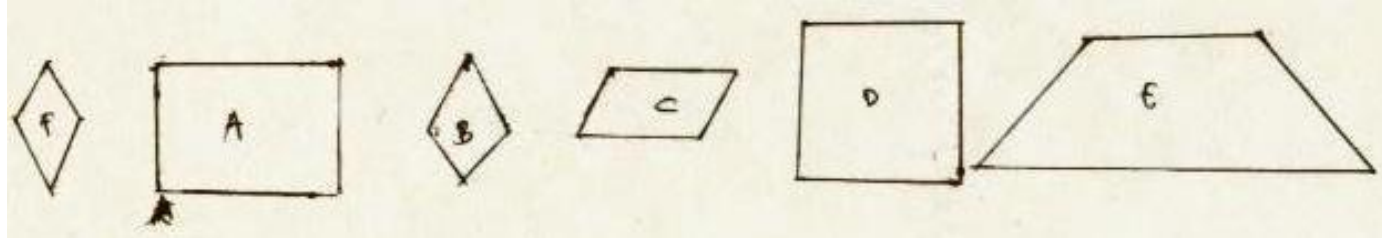

Gambar 3. Macam Segiempat menurut S3

Tingkat berpikir siswa S3 lebih banyak pada tingkat berpikir analisis (1). Jadi dapat disimpulkan bahwa siswa S3 tingkat berpikirnya terletak pada tingkat berpikir analisis (1).

Analisis data berpikir siswa S4 adalah sebagai berikut, siswa S4 hanya dapat menggambar 5 segiempat. Adapun kelima gambar segiempat tersebut dapat dilihat pada gambar 4.

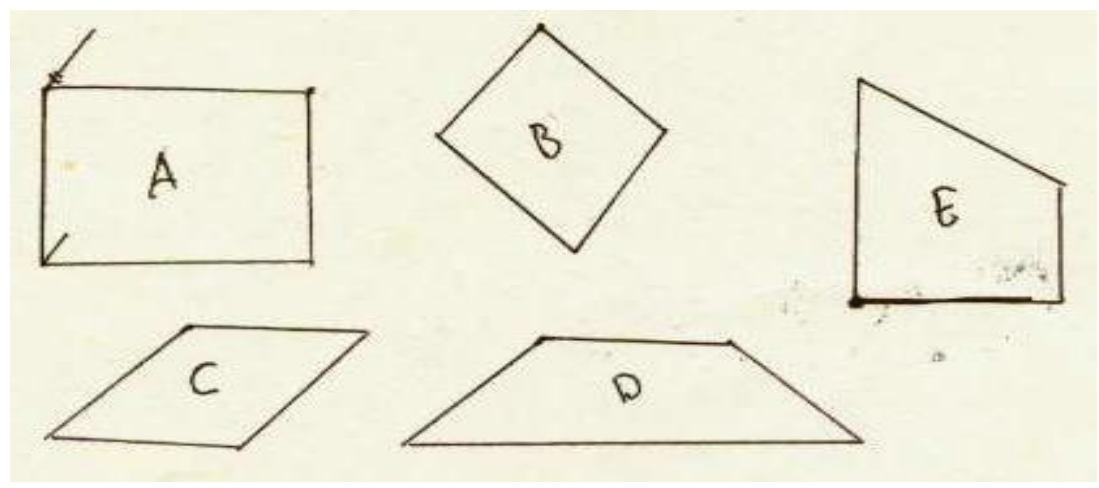

Gambar 4. Macam Segiempat menurut S4 
Tingkat berpikir siswa S4 lebih banyak pada tingkat berpikir analisis (1), meskipun pada siswa S4 masih belum begitu memahami tentang sifat-sifat yang dimiliki bangun trapesium, yaitu tepat memiliki satu pasang sisi yang sejajar. Jadi dapat disimpulkan bahwa tingkat berpikir siswa S4 berada pada tingkat berpikir analisis (1).

Analisis data berpikir siswa S5 adalah sebagai berikut, siswa S5 hanya dapat menggambar 4 segiempat. Adapun keenam gambar segiempat tersebut adalah sebagai berikut.

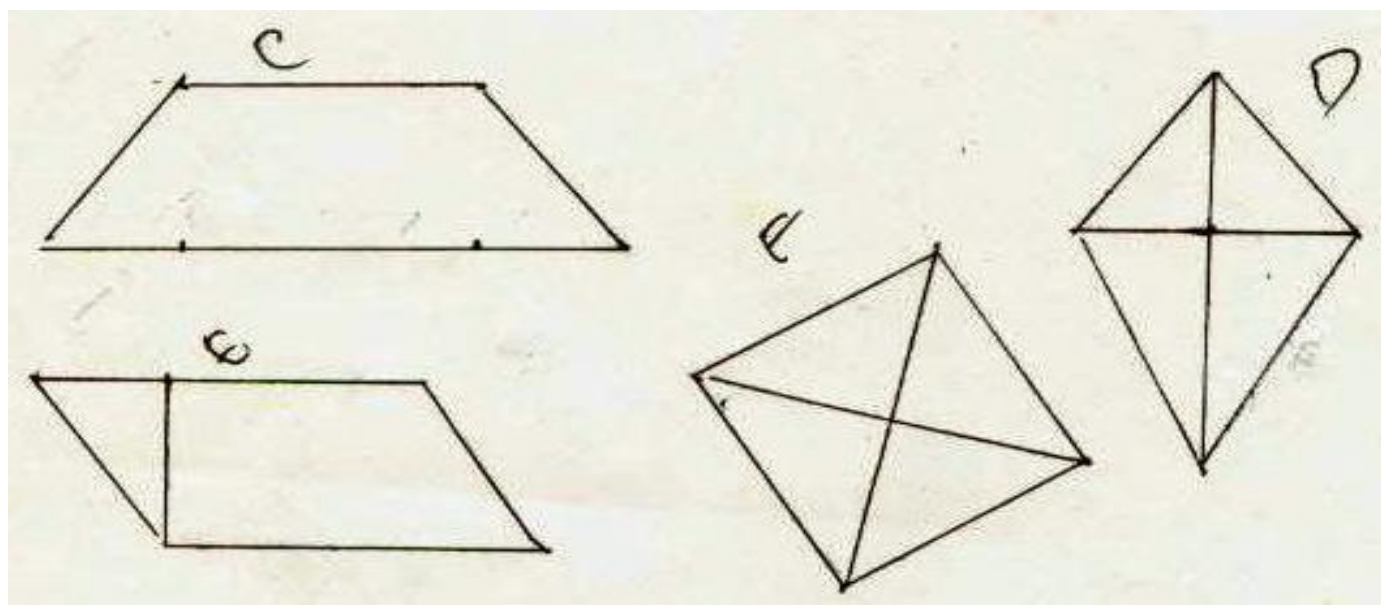

Gambar 5. Macam Segiempat menurut S5

tingkat berpikir siswa S5 lebih banyak pada tingkat berpikir visualisasi (0), hal ini dimungkinkan siswa masih belum memahami class inclusion dari bangun-bangun segiempat, selain itu siswa S5 juga masih belum memahami tentang simetri putar dan banyak cara dari bangun segiempat menempati bingkainya. Sehingga disimpulkan bahwa tingkat berpikir siswa S5 berada pada tingkat berpikir visualisasi (0).

Analisis data berpikir siswa S6 adalah sebagai berikut, siswa S6 hanya dapat menggambar 5 segiempat. Adapun kelima gambar segiempat tersebut adalah sebagai berikut.

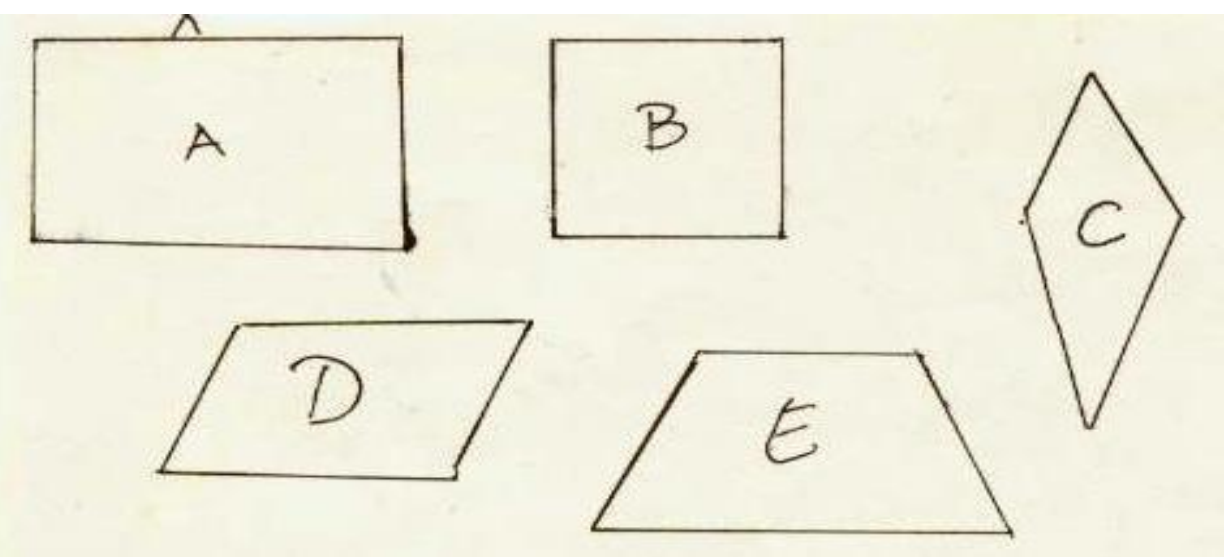

Gambar 6. Macam Segiempat menurut S6

Tingkat berpikir siswa S6 lebih banyak pada tingkat berpikir visualisasi (0). Dari hasil wawancara, terlihat siswa S6 masih belum menguasai tentang materi bangun segiempat, hal ini terlihat saat siswa menggunakan sifat-sifat yang tidak tepat dalam menyebutkan ciri-ciri bangun segiempat. Sehingga 
siswa tidak begitu memahami class inclusion dari bangun-bangun segiempat. Jadi dapat disimpulkan bahwa tingkat berpikir siswa S6 berada pada tingkat berpikir visualisasi (0).

Dari hasil analisis tingkat berpikir tiap siswa, didapatkan tingkat berpikir van Hiele ditinjau dari kemamuan matematika dan gender, dapat dilihat pada tabel berikut.

Tabel 1. Tingkat Berpikir Siswa Level Van Hiele

\begin{tabular}{|c|c|c|c|}
\hline \multicolumn{2}{|c|}{ Siswa Laki-laki } & \multicolumn{2}{c|}{ Siswa Perempuan } \\
\hline Kode Subjek & Tingkat Berpikir & Kode Subjek & Tingkat Berpikir \\
\hline S1 & 1 & S4 & 1 \\
S2 & 1 & S5 & 0 \\
S3 & 1 & S6 & 0 \\
\hline
\end{tabular}

Dari hasil analisis data, secara umum terlihat bahwa tingkat berpikir subjek penelitian berada pada tingkat 1 (analisis) dan hanya satu siswa yang berada di tingkat berpikir 0 (visualisasi) pada materi segiempat. Ini berarti bahwa subjek penelitian belum mencapai tingkat berpikir 2 (abstraksi) seperti yang diungkapkan van Hiele. Van Hiele mengatakan bahwa tingkat berpikir 2 merupakan tingkat berpikir ideal yang harus dimiliki siswa SMP. Sehingga dapat dikatakan bahwa siswa yang berada pada tingkat berpikir 0 hanya mampu mengenali bangun-bangun segiempat berdasarkan pertimbangan visual. Siswa masih menggunakan sifat-sifat yang tidak tepat untuk membedakan, mengidentifikasi, dan memilih bangun-bangun geometri. Sedangkan subjek penelitian yang berada pada tingkat berpikir 1, sudah mulai memperhatikan bagian-bagian dari bangun segiempat, seperti sisi-sisinya dan sudut sudutnya. Siswa sudah mulai mampu menggunakan sifat-sifat yang tepat dalam membedakan, mengidentifikasi, dan memilih bangun-bangun geometri, meskipun ada siswa yang menggunakan sifat yang tidak relevan dalam menyebutkan sifat bangun segiempat.

Temuan yang cukup menarik adalah siswa masih belum memahami tentang class inclusion, meskipun telah diberikan bantuan berupa tabel sifat-sifat segiempat. Selain itu masih banyak siswa yang masih belum membayangkan bahwa ada banyak tak terhingga bangun segiempat berbeda yang dapat digambar.

Ada beberapa temuan lain selama pengumpulan data yang dapat menjadi kendala bagi peningkatan tingkat berpikir subjek penelitian. Diantaranya adalah kendala bahasa. Banyak subjek penelitian yang menggunakan bahasa geometri berupa kata-kata yang tidak tepat, misalnya: "Karena segitiga lebih kecil daripada persegi panjang B", "Satu pasang yang berhadapan sama panjang", "diagonalnya membelah sama besar".

\section{KESIMPULAN}

Hasil penelitian ini dapat disimpulkan bahwa ada perbedaan antara tingkat berpikir siswa lakilaki dan perempuan berdasarkan tingkat berpikir van Hiele. Ada tiga subjek laki-laki yang memiliki kemampuan matematika tinggi, sedang dan rendah dan satu subjek perempuan yang memiliki matematika rendah berada pada tingkat berpikir visualisasi dari tingkat berpikir van Hiele sedangkan 
ada dua subjek perempuan yang memiliki kemampuan matematika tinggi dan sedang berada pada tingkat berpikir analisis dari tingkat berpikir van Hiele. Subjek memiliki kelemahan dalam hal menggunakan sifat-sifat yang tidak tepat untuk membedakan, mengidentifikasi, dan memilih bangunbangun geometri. Subjek penelitian juga tidak dapat membayangkan bahwa banyaknya bangun segiempat berbeda. Dan hampir semua subjek dalam penelitian ini masih mengabaikan class inclusion bangun-bangun segiempat meskipun mereka telah mampu membedakan bangun-bangun geometri berdasarkan sifat-sifat komponennya.

\section{UCAPAN TERIMA KASIH}

Dengan seslesainya proses dan hasil penelitian ini, saya mengucapkan terima kasih brlimph kepada orang tua, suami, seluruh dosen Program Studi Pendidikan Matematika FKIP Universitas Flores dan semua pihak yang terlibat dalam penlitian saya ini, sehingga dapat terlaksana dengan bak, lancar dan sukses.

\section{REFERENSI}

Burger, William F \& Shaughnessy, J. Michael. 1986. "Characterizing The van Hiele Levels of Development in Geometry." Journal for Research in Mathematics Education 17(1): 1.

Kho, Ronaldo. 1996. "Tahap Berpikir Dalam Belajar Geometri Siswa SMP." Universitas Negeri Surabaya.

Krutetskii. 1976. The Psychology of Mathematics Abilities in Schoolchildren. USA: University of Chicago.

Lexy. J Moleong. 2013. Metode Penelitian Kualitatif. Bandung: Edisi Revisi, Bandung.

Maccoby, E.E. \& Jacklin, C.N. 1985. The Psychology of Sex Differences. California. Stanford University.

Musa, L.A.D. 2016. "Level Berpikir Geometri Menurut Teori van Hiele Berdasarkan Kemampuan Berpikir Geometri.” Jurnal Pendidikan Matematika dan Sains 4(2): 103-6.

Ponter. 2001. "Pemahaman Siswa SMP Terhadap Soal Cerita Geometri." Universitas Negeri Surabaya. Soedjadi. 1991. Wajah Pendidikan Matematika Di Sekolah Dasar. Jakarta: Calon Penatar Dosen PGSD Guru Kelas.

Soedjadi. 1994. 3 Pendidikan Matematika Nasional Memantapkan Matematika Sekolah Sebagai Wahana Pendidikan Dan Pembudayaan Penalaran. Surabaya: Program Pasca Sarjana Universitas Negeri Surabaya.

Soedaji. 2020. Kiat-Kiat Pendidikan Matematika Di Indonesia. Jakarta: Direktorat Jendral Pendidikan Tinggi Departemen Pendidikan Nasional.

Sunardi. 2020. "Tingkat Perkembangan Konsep Geometri Siswa Kelas VII SMP.” Universitas Negeri Surabaya.

Suwarsono, St. 1990. 1 Potensi Geometri Dalam Pengajaran Matematika. Widya Dharma. 
Tingkat Berpikir Siswa dalam Memecahkan Masalah Geometri Bangun Datar Ditinjau dari Kemampuan Matematika dan Gender, Finsensius Y. Naja, Sofia Sa'o, Agustina Mei

Suyatno. 2005. "Penulusuran Tahap Berpikir Geometri VanHiele Siswa." Program Pascasarjana Universitas Negeri Surabaya.

Van de Walle, J.A. 2001. Geometri Thinking and Geometric Concept in Elementary and Middle School Mathematics Teaching Developmentally. Boston: 4 td ed. Boston: Pearson Education. 